\title{
Residue and Sucker Control from Two Formulations of Maleic Hydrazide (MH) *
}

by

\section{T. J. Sbeets}

Pesticide Residue Research Laboratory, North Carolina State University, Raleigh, North Carolina, U.S.A.

and

Heinz Seltmann

U.S. Department of Agriculture, Agricultural Research Service and

Department of Botany, North Carolina State University,

Raleigh, North Carolina, U.S.A.

\section{SUMMARY}

Data from experiments conducted at one location in 1980 and two in 1981 showed that MH residues were greater on flue-cured tobacco after application of a $\mathrm{K}-\mathrm{MH}$ (potassium salt of $\mathrm{MH}$ ) formulation than of a DEA-MH (diethanolamine salt of MH) formulation at the same rate of active ingredient. On cured lamina mean residue values from $\mathrm{K}-\mathrm{MH}$ for the two locations in 1981 were $48 \%$ and $61 \%$ greater than those for DEA-MH. There was no apparent loss of residue for either formulation during the curing process. Sucker control was less efficient with the DEA-MH than with the $\mathrm{K}-\mathrm{MH}$ formulation and was associated with the level of residue in the leaf.

\section{ZUSAMMENFASSUNG}

Feldversuche (im Jahre 1980 an einem Ort und 1981 an zwei Orten durchgeführt) zeigten, daß der Gehalt an Rückständen von Maleinsāurehydrazid (MH) in Virginia-Tabak nach Applikation des Mittels in Form seines Kaliumsalzes (K-MH) auf der Basis gleicher Wirkstoffkonzentration größer war, als wenn es in Form seines

\footnotetext{
* Received: 8th November 1983 - accepted: 11 th September 1984.

Paper No. 8910 of the Journal Series of the North Carolina Agricultural Research Service, Raleigh, N.C. Cooperative investigations of the N. C. Agricultural Research Service and the U.S. Department of Agriculture, Agricultura Research Service.

Use of trade names in this publiction does not imply endorsement of the products named or criticism of similar ones not mentioned.
}

Diethanolaminsalzes (DEA-MH) angewendet worden war. Bei den zwei Versuchen des Jahres 1981 lagen die Rückstandsmengen im getrockneten Blattgewebe, wenn sie auf die Anwendung von K-MH zurückzuführen waren, um durchschnittlich $48 \%$ bzw. $61 \%$ über den von DEA-MH herrührenden Werten. Bei keiner der beiden Verbindungsformen wurde eine Verminderung der Rückstände während des Trocknungsprozesses beobachtet. Das Ausmaß der Hemmung des Geizenwachstums war bei Applikation von DEA-MH schwächer, als wenn K-MH angewendet wurde, und korrelierte mit dem Rückstandsgehalt des Blattgutes.

\section{RÉSUMÉ}

Des essais de plein champ (réalisés en un même lieu en 1980 et en deux endroits en 1981) ont montré que la teneur du tabac de Virginie en résidus d'hydrazide maléique $(\mathrm{MH})$ après application du produit sous forme de sel de potassium (K-MH) était plus élevée qu'en cas d'application sous forme de sel diéthanolaminé (DEAMH), la concentration en agent actif étant la même. Dans le cas des deux expériences effectuées en 1981, les résidus contenus dans le tissu foliaire séché, suite à l'application de $\mathrm{K}-\mathrm{MH}$, dépassaient en moyenne respectivement de $48 \%$ et $61 \%$ les quantités obtenues avec le DEA-MH. Une diminution de la teneur en résidus au cours du séchage ne fut observée pour aucun des deux composés. L'inhibition de la croissance des bourgeons est apparue moins efficace dans le cas de l'application de DEA-MH que dans celui du $\mathrm{K}-\mathrm{MH}$, et elle est en relation avec la teneur en résidus dans les feuilles. 


\section{IN'TRODUCTION}

Two formulations of 1,2-dihydro-3,6-pyridazinedione $(\mathrm{MH})$, that contain either the diethanolamine salt (DEA-MH) or the potassium salt (K-MH), have been used extensively throughout the tobacco growing regions of the United States for control of axillary buds (suckers) on tobacco (Nicotiana tabacum L.). In recent years MH use has spread to other countries where tobacco is produced, but in a few countries like Canada and Zimbabwe MH application to tobacco is prohibited. Of the two salts, the K-MH form remains available for tobacco sucker control in the United States. The DEA-MH is rapidly becoming unavailable because a decision by the U.S. Environmental Protection Agen$c y$ in 1982 required additional data for the continued labeling and sale of DEA-MH for tobacco. However, no data were presented.

Field observations have shown that, at equivalent application rates of the active ingredient, the $\mathrm{K}-\mathrm{MH}$ formulation often controlled suckers better than the DEAMH $(1,2)$; but in some tests, sucker control from the two formulations was not different (10). The better control may be attributed to greater absorption of $\mathrm{MH}$ from the K-MH formulation than from the DEA-MH when the two forms were applied under identical environmental conditions. However, in early work with tomato the unformulated DEA-MH was absorbed more efficiently than the unformulated K-MH (9). MH is not readily metabolized in plants; hence, if the $\mathrm{K}-\mathrm{MH}$ form is absorbed more readily into tobacco leaves than DEA-MH, less would remain on the leaf surface where weathering processes, especially rainfall, could remove or alter it. The greater absorption of $\mathrm{X}-\mathrm{MH}$ also may result in higher residue at harvest than with DEA-MH. An opportunity to test this presumption occurred in 1980 in the process of producing experimental tobacco for a cooperator. Further investigations were. performed at two locations in 1981 to compare the residue from the two formulations. A secondary objective was to determine if the flue-curing process altered the residue remaining from the two formulations.

\section{EXPERIMENTAL PROCEDURES}

The 1980 experiment was established on a Norfolk loamy sand in Johnston County, North Carolina. Plants of flue-cured tobacco (Nicotiana tabacum L. cv. McNair 944) were transplanted May 7, and recommended cultural practices were used throughout the growing season. Pesticides employed in the general culture of the tobacco included $O$-ethyl $S, S$-dipropyl phosphorodithioate (ethoprop) at $2.2 \mathrm{~kg} / \mathrm{ha}, 2,6$-dinitro- $N, N$-dipropylcumidine (isopropalin) at $1.7 \mathrm{~kg} / \mathrm{ha}$ and $N, N$-dimethyl-2,2-diphenylacetamide (diphenamid) at $4.5 \mathrm{~kg} / \mathrm{ha}$ before planting; one application of $S$-methyl $\quad N$-[(methylcarbamoyl)oxy]thioacetimidate (methomyl) at $0.4 \mathrm{~kg} / \mathrm{ha}$ and two applications of $0,5-$ dimethyl $\mathrm{N}$-acetylphosphoramidothioate (acephate) at $0.8 \mathrm{~kg}$ / ha were made to the foliage during the growing season. A contact sucker control chemical [mainly 1-octanol and 1-decanol: $\mathrm{C}_{6}(0.5 \%), \mathrm{C}_{8}(42 \%), \mathrm{C}_{10}$ $\left.(56 \%), \mathrm{C}_{12}(1.5 \%)\right]$ was applied July 16 at a rate of 5.7 liters/ha on all plots.

$\mathrm{MH}$ as the DEA-MH and K-MH formulations was applied at 2.5 and $5.0 \mathrm{~kg}$ / ha on July 23, 1 week after the contact agent. A back-pack sprayer equipped with a three-nozzle boom (7) was used to apply MH solutions at a diluent rate of 470 liters / ha. A heavy rain measuring $4.4 \mathrm{~cm}$ began falling within $2 \mathrm{~h}$ after spraying, and the plots were retreated with the same rates on July 24 . Plots were $12.3 \mathrm{~m}$ long and with a row spacing of $1.2 \mathrm{~m}$. The plants were spaced $0.56 \mathrm{~m}$ in the rows $(22$ plants per row). There were two guard rows between plots. The experimental design was a randomized block with two replications.

The tobacco was harvested once before $\mathrm{MH}$ was applied and three additional times as the leaves matured. After application of $\mathrm{MH}$, each harvest was sampled by removing two $5 \mathrm{~cm}$ discs from the lamina of each of 100 leaves per plot. The green discs were frozen immediately and stored for residue analysis later. All leaves (the 100 from which discs had been removed plus the remainder) were cured. After curing, midribs were stripped from 50 randomly selected leaves and the aggregate lamina sample was saved for residue analysis.

The 1981 experiment was established with McNair 944 in Johnston County on a Marlboro loamy sand on May 4 and in Rockingham County, North Carolina, on an Appling sandy loam May 18, 1981. The cultural practices, application methods and sampling techniques were similar to those described above. Each formulation of MH was applied once at $2.5 \mathrm{~kg} / \mathrm{ha}$ a.i. before the first harvest, and treatments were replicated four times in a randomized block design. There was one guard row between plots. Yield of cured leaf was determined and suckers were counted and weighed after the last harvest.

The analytical procedure for MH was similar to that described by Lane (6) and used recently by Hunt et al. (5) and others, except that the decolorizing charcoal step (addition of activated charcoal to the hydrazine distillate just before color development) was included as prescribed in the proposed Coresta method No. 4 (3). Residue values for both green and cured leaf are based on $13 \%$ moisture.

\section{RESULTS AND DISCUSSION}

Data from the 1980 preliminary experiment showed that $\mathrm{MH}$ at the $2.5 \mathrm{~kg}$ / ha rate resulted in residue values of the same magnitude for the DEA-MH and the $\mathrm{K}-\mathrm{MH}$ formulations on both green and cured tobacco (Table 1). At the $5.0 \mathrm{~kg}$ / ha rate for green tobacco, the residue for the $\mathrm{K}-\mathrm{MH}$ (average of $429 \mathrm{ppm}$ on green lamina) was significantly greater than that for the 
Table 1.

MH residue in 1980 from DEA-MH and K-MH formulations before and after curing (based on $13 \%$ molsture).

\begin{tabular}{|c|c|c|c|c|}
\hline \multirow{2}{*}{$\begin{array}{l}\text { Formu- } \\
\text { lation }\end{array}$} & \multirow{2}{*}{$\begin{array}{l}\text { Rate of } \\
\text { appli- } \\
\text { cation } \\
(\mathrm{kg} / \mathrm{ha})\end{array}$} & \multirow[b]{2}{*}{ Harvest } & \multicolumn{2}{|c|}{ Lamina* } \\
\hline & & & $\begin{array}{l}\text { green } \\
\text { (ppm) }\end{array}$ & $\begin{array}{l}\text { cured } \\
\text { (ppm) }\end{array}$ \\
\hline \multirow[t]{8}{*}{ DEA-MH } & 2.5 & second & 132 & 93 \\
\hline & & third & 194 & 170 \\
\hline & & fourth & 95 & 142 \\
\hline & & $\begin{array}{c}\text { Mean } \\
\text { (numerical) }\end{array}$ & $140 \mathrm{c}$ & $135 b$ \\
\hline & 5.0 & second & 274 & 308 \\
\hline & & third & 314 & 317 \\
\hline & & fourth & 172 & 208 \\
\hline & & $\begin{array}{c}\text { Mean } \\
\text { (numerical) }\end{array}$ & $253 \mathrm{~b}$ & $278 a$ \\
\hline \multirow[t]{8}{*}{$\mathrm{K}-\mathrm{MH}$} & 2.5 & second & 146 & 107 \\
\hline & & third & 210 & 173 \\
\hline & & fourth & 100 & 110 \\
\hline & & $\begin{array}{c}\text { Mean } \\
\text { (numerical) }\end{array}$ & $152 b c$ & $130 \mathrm{~b}$ \\
\hline & 5.0 & second & 489 & 418 \\
\hline & & third & 499 & 462 \\
\hline & & fourth & 399 & 296 \\
\hline & & $\begin{array}{c}\text { Mean } \\
\text { (numerical) }\end{array}$ & $429 a$ & $392 \mathrm{a}$ \\
\hline
\end{tabular}

* Numerical means within columns and with the same letter are not significantly different at the $5 \%$ level. Harvest means and the MH rate $\times$ harvest interaction were significant.

DEA-MH (average of $253 \mathrm{ppm}$ on green lamina). The corresponding means for cured lamina were not significantly different, but the spread was rather large and the difference approached significance. In this experiment the measured values for the residue from the $\mathrm{K}-\mathrm{MH}$ formulation on cured lamina were generally lower than those for green lamina.

In 1981, the $\mathrm{MH}$ residue from the $\mathrm{K}-\mathrm{MH}$ formulation was greater than that from the DEA-MH at both locations (Tables 2 and 3). On cured lamina the weighted average for $\mathrm{K}-\mathrm{MH}$ at the Johnston County and Rockingham County locations was, respectively, $48 \%$ and

Table 3.

Welghted average residue (over harvests) from application of DEA-MH and K-MH formulations at two locations in 1981.

\begin{tabular}{l|c|c|c}
\hline Chemical & $\begin{array}{c}\text { Johnston } \\
\text { County } \\
(\mathrm{ppm})\end{array}$ & $\begin{array}{c}\text { Rockingham } \\
\text { County } \\
(\mathrm{ppm})\end{array}$ & $\begin{array}{c}\text { Means } \\
(\mathrm{ppm})\end{array}$ \\
\hline DEA-MH & 21 & 101 & 61 \\
K-MH & 31 & 163 & 97 \\
Control $^{*}$ & $<10$ & $<10$ & $<10$ \\
Significance level & 0.06 & 0.03 & $<0.01$ \\
\hline
\end{tabular}

*Values for controls were omitted from the analysis of variance.
Table 2.

MH residue in 1981 from DEA-MH and K-MH formulatlons before and after curing (based on $13 \%$ molsture).

\begin{tabular}{|c|c|c|c|c|c|}
\hline \multirow{2}{*}{$\begin{array}{l}\text { Chemi- } \\
\text { cal }\end{array}$} & \multirow{2}{*}{ Harvest } & \multicolumn{2}{|c|}{ Johnston County* } & \multicolumn{2}{|c|}{ Rockingham County* } \\
\hline & & $\begin{array}{l}\text { green } \\
\text { (ppm) }\end{array}$ & $\begin{array}{l}\text { cured } \\
\text { (ppm) }\end{array}$ & $\begin{array}{l}\text { green } \\
\text { (ppm) }\end{array}$ & $\begin{array}{l}\text { cured } \\
\text { (ppm) }\end{array}$ \\
\hline \multirow[t]{6}{*}{ DEA-MH } & first & 86 & 78 & 130 & 122 \\
\hline & second & 25 & 23 & 134 & 128 \\
\hline & third & 13 & 13 & 70 & 83 \\
\hline & fourth & 20 & $<10$ & 76 & 84 \\
\hline & fifth & 15 & 16 & & \\
\hline & $\begin{array}{c}\text { Mean } \\
\text { (numerical) }\end{array}$ & 32 & 27 & 103 & 104 \\
\hline \multirow[t]{6}{*}{ K-MH } & first & 87 & 80 & 143 & 142 \\
\hline & second & 30 & 27 & 194 & 195 \\
\hline & third & 19 & 20 & 140 & 165 \\
\hline & fourth & 19 & 16 & 135 & 150 \\
\hline & fifth & 31 & 30 & & \\
\hline & $\begin{array}{c}\text { Mean } \\
\text { (numerical) }\end{array}$ & 37 & 35 & 153 & 163 \\
\hline $\begin{array}{l}\text { Significa } \\
\text { of mean }\end{array}$ & $\theta$ level & 0.12 & 0.02 & $<0.01$ & $<0.01$ \\
\hline
\end{tabular}

* The values for harvests were significant at 0.01 level for both green and cured lamina at both locations. The interaction $F$ values were not significant at the 0.05 level.

$61 \%$ greater than that for DEA-MH. Although data from the 1980 experiment suggested that a loss of $\mathrm{K}-\mathrm{MH}$ occurred during curing (Table 1), this effect was not confirmed in 1981; and the residue from neither formulation was affected by flue curing (Table 2).

In 1980 , residues remaining on cured lamina from the $2.5 \mathrm{~kg} / \mathrm{ha}$ rate of the DEA-MH and the K-MH formulations averaged 135 and $130 \mathrm{ppm}$, respectively (Table 1). In 1981, residues for the Johnston County site were exceptionally low and the values for the Rockingham County location were approximately four to five times greater than those for Johnston County (Tables 2 and 3). Variations of this magnitude are not unusual and may be attributed to differences in the amounts and times of rainfall as well as the time between $\mathrm{MH}$ application and harvest $(4,8)$.

The residue values in Tables 1, 2 and 3 are for lamellar tissues only. The residue for whole leaves was known from previous research to be about 0.77 times that in the lamina (unpublished data). Thus, the residues in Tables 1 and 2 should be multiplied by 0.77 to obtain an estimate of the concentration on a whole-leaf basis. Published values have often been based on the whole leaf (5).

Recovery of the applied MH was estimated from yields 'and residues by harvests. The percentages are based on an application rate of $2.5 \mathrm{~kg} / \mathrm{ha}$. Total recovery amounted to 1.6 and $2.5 \%$, respectively, for the DEA$\mathrm{MH}$ and $\mathrm{K}-\mathrm{MH}$ formulations at the Johnston County location and 5.3 and $8.2 \%$, respectively, for the DEA$\mathrm{MH}$ and $\mathrm{K}-\mathrm{MH}$ formulations at the Rockingham 
Table 4.

Sucker control after appllcation of DEA-MH and K-MH formuIations at two locations in 1981.

\begin{tabular}{l|c|c}
\hline Chemical & $\begin{array}{c}\text { Johnston County } \\
(\%)\end{array}$ & $\begin{array}{c}\text { Rockingham County* } \\
(\%)\end{array}$ \\
\hline DEA-MH & 50 & 95 \\
K-MH & 80 & 98 \\
Significance level & 0.02 & 0.08 \\
\hline
\end{tabular}

"The weight of suckers from plots that recelved one application of the contact sucker control chemical but no MH was used as a base to calculate percent control."

County location. The difference in the amounts directed toward the plants and the amounts recovered reflected incomplete deposit of the $\mathrm{MH}$ at application, losses from wash-off by rainfall, photodecomposition on the leaf surface, and translocation of absorbed $\mathrm{MH}$ into plant parts not harvested.

The data on control of suckers in Table 4 confirmed results of Collins et al. $(1,2)$. The percent control was greater for the K-MH formulation than for the DEAMH. The more effective control of tobacco suckers with the $\mathrm{K}-\mathrm{MH}$ formulation can be explained by the greater absorption of $\mathrm{MH}$ which is reflected in the higher residue levels. If enough DEA-MH formulation were used to provide sucker control equivalent to that obtained with 2 given rate of the $\mathrm{K}-\mathrm{MH}$, the residue from the two formulations would likely be more similar. Futhermore, with the K-MH formulation less total $\mathrm{MH}$ would be added to the environment.

\section{REFERENCES}

1. Collins, W. K., S. N. Hawks, Jr., and B. U. Kittrell: Effects of systemics alone and contacts followed by a systemic sucker control agent on some agronomic-economic characteristics of flue-cured tobacco; Tob. Sci. 14 (1970) 86-88.

2. Collins, W. K., S. N. Hawks, Jr., and B. U. Kittrell: Comparison of MH-30 and Royal MH-30 on sucker control and yield and value of flue-cured tobacco; Tob. Sci. 15 (1971) 106.
3. Coresta Recommended Method No. 4 (September 1976): Determination of maleic hydrazide residues in tobacco; Coresta Information Bulletin 1976-2, 29-36.

4. Davis, D. L., W. O. Atkinson and J. Smiley: Maleic hydrazide residue from air-cured Burley tobacco; Crop Sci. 14 (1974) 109-112.

5. Hunt, T. W., T. J. Sheets and W. K. Collins: MH residues on flue-cured tobacco; Tob. Sci. 21 (1977) 128-130.

6. Lane, J. R.: Collaborative study of maleic hydrazide residue analysis; J. Assoc. Off. Agric. Chem. 46 (1963) 261-268.

7. Seltmann, H., and J. A. Priest: Simulation of machine application with hand-held equipment; Tob. Sci. 16 (1972) 100.

8. Sheets, T. J., and H. Seltmann: Effect of sprinkler irrigation on tobacco sucker control and residue from MH; Tob. Sci. 26 (1982) 106-108.

9. Smith, A. E., J. W. Zukel, G. M. Stone and J. A. Riddell: Factors affecting the performance of maleic hydrazide; J. Agric. Food Chem. 7 (1959) 341-344.

10. Wolfe, Ronald: Comparison of Burley tobacco topped and suckered by chemicals and by hand; Tob. Sci. 15 (1977) 151.

\section{Acknowledgement}

This work was supported in part by grants from the North Carolina Tobacco Foundation, the American Tobacco Company, Brown and Williamson Tobacco Corporation, P. Lorillard Corporation, Philip Morris, R. J. Reynolds Tobacco Company, and the Tobacco Advisory Committee (United Kingdom).

The technical assistance of Patricia L. Messick in performing the $M H$ analyses is gratefully acknowledged.

\author{
Autbors' address: \\ Pesticide Residue Research Laboratory, \\ North Carolina State University, \\ Raleigh, North Carolina, 27695, U.S.A.
}

